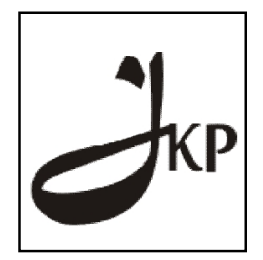

Jurnal Konseling dan Pendidikan

ISSN Cetak: 2337-6740 - ISSN Online: 2337-6880

http://jurnal.konselingindonesia.com

Volume 3 Nomor 3, November 2015, HIm 67-75

Info Artikel:

Diterima 06/10/2015

Direvisi 03/11/2015

Dipublikasikan 28/11/2015

\title{
PENINGKATAN HASIL BELAJAR PESERTA DIDIK MELALUI METODE PROBLEM SOLVING DALAM PELAJARAN MATEMATIKA KELAS IV SDN 12 NAN SABARIS
}

Zulmaini

\begin{abstract}
Indonesian society progress and communication technology very rapidly. Therefore, it needs qualified human resources. Forming qualified human resources that can be done through formal education. In fact a lot of students who are less able to get a satisfactory learning outcomes. Therefore in inidicobakan research using methods Problem Solving in mathematics in grade IV SDN 12 Nan Sabaris. The formulation of this research is how the result of learning mathematics in grade IV SDN 12 Nan Sabaris Padang Pariaman using methods of problem solving? This study uses a classroom action research with two cycles. The survey results revealed that students' mathematics learning outcomes increased from the first cycle to the second cycle. This proves that the method of problem solving can improve students' mathematics learning outcomes.
\end{abstract}

Keyword: learning outcomes, problrm solving, math.

Copyright (C) 2015 IICET (Padang - Indonesia) - All Rights Reserved

Indonesian Institute for Counseling, Education and Theraphy (IICET)

\section{PENDAHULUAN}

Meningkatkan sumber daya manusia merupakan tugas seorang pendidik. Pendidik adalah manusia yang memegang peranan penting dalam kemajuan peserta didik yang dididiknya dalam menghadapi kemajuan teknologi dan informasi yang sangat pesat dan semakin menyentuh seluruh aspek kehidupan manusia. Seperti yang diungkapkan oleh Soedjadi $(2000 ; 137)$ bahwa : "Untuk menghadapi abad ke-21 yang diperkirakan akan diwarnai oleh persaingan, bangsa Indonesia mutlak perlu memiliki warga yang bermutu atau yang berkualitas tinggi”. Jadi salah satu jalan untuk menghadapi semua itu adalah dengan jalur pendidikan, yang mana pendidik merupakan pentransferan ilmu pada peserta didiknya, baik melalui jalur formal maupun nonformal.

Banyak kenyataan yang kita temukan di lapangan bahwa peserta didik kurang memahami materi yang diajarkan. Ini dapat dilihat dari hasil kerja peserta didik yang kurang memuaskan. Nilai Matematika pada prasiklus peserta didik kelas IV dengan rata-rata kelas sekitar 4,90. Penyebab terjadi hal ini tidak sepenuhnya terdapat pada peserta didik, guru juga punya andil besar terhadap rendahnya hasil belajar matematika peserta didik, seperti guru kurang mengawasi peserta didik dalam mengerjakan latihan. Guru lebih cendrung memberikan latihan beberapa buah soal, tanpa mengontrol apakah masing-masing individu peserta didik sudah dapat menyelesaikan soal-soal yang berkaitan dengan materi yang dijelaskan. Di samping itu guru yang kurang mengontrol pekerjaan peserta didik, apakah peserta didik mengerjakan sendiri tugasnya atau hanya membuat tugas dari hasil contekan temannya.

Winataputra (1997 : 25) lebih jelas menggambarkan Hasil belajar berupa perubahan perilaku atau tingkah laku. Seseorang belajar akan berubah atau bertambah perilaku, baik yang berupa pengetahuan, keterampilan motorik atau penguasaan nilai-nilai (sikap). Berdasarkan masalah yang ditemui oleh peneliti selama mengajar di kelas IV SDN 12 Nan Sabaris, maka masalah tersebut di atas dapat diidentifikasi beberapa permasalahan yang dihadapi dalam pembelajaran Matematika khususnya mengenai kompetensi dasar tentang menentukan KPK dan FPB di kelas IV semester I SDN 12 Nan Sabaris, Kabupaten Padang Pariaman sebagai berikut :

1. Nilai rata-rata peserta didik setiap dilakukan latihan selalu rendah

2. Kurangnya motivasi peserta didik dalam belajar matematika di sekolah

3. Kemampuan peserta didik kelas IV Sekolah Dasar Negeri 12 Nan Sabaris Kecamatan Nan Sabaris dalam perkalian dan pembagian masih sangat kurang. 
4. Penggunaan metode pembelajaran yang digunakan pendidik masih kurang tepat, sehingga banyak bagi peserta didik yang belum hafal perkalian dan pembagian

Dengan adanya penjelasan pada latar belakang dan indentifikasi masalah di atas, dapat dikemukakan rumusan masalah yang akan dipecahkan melalui penelitian tindakan kelas adalah bagaimanakah hasil belajar matematika di kelas IV SDN 12 Nan Sabaris Kabupaten Padang Pariaman menggunakan metode problem solving?

Penelitian tindakan kelas ini bertujuan untuk memperbaiki cara pembelajaran peneliti yang selama ini masih kurang berhasil, pada akhir penelitian ini juga sangat diharapkan terjadinya peningkatan hasil belajar Matematika melalui penggunaan metode problem solving di kelas IV SDN 12 Nan Sabaris Kabupaten Padang Pariaman. Penelitian ini menggunakan metode problem solving yang merangsang berfikir siswa dan menggunakan wawasan tanpa melihat kualitas pendapat yang disampaikan oleh peserta didik dan gurupun harus pandai-pandai merangsang peserta didiknya untuk mencoba mengeluarkan pendapat. Metode problem solving merupakan metode yang dapat digunakan dalam proses belajar mengajar. Hal ini sesuai dengan pendapat Hyman yang dikutip Mudjiono (1992 : 67) mengemukakan bahwa :

"Metode problem solving dapat diartikan sebagai suatu format interaksi belajar mengajar yang ditandai adanya satu atau lebih tugas yang diberikan oleh guru, di mana penyelesaian tugas tersebut dapat dilakukan secara perorangan atau secara kelompok sesuai dengan perintahnya".

Selanjutnya Tarmudji (1983 : 35) mengemukakan bahwa "Metode problem solving adalah suatu cara menyajian materi yang dicapai dengan jalan memberikan tugas-tugas kepada peserta di luar kegiatan rutinnya sehingga peserta tetap terlihat ada kegiatan". Metode problem solving bermaksud meninjau pelajaran baru untuk menghapal pelajaran yang sudah diajarkan, untuk latihan-latihan, dengan tugas untuk mengumpulkan bahan, untuk memecahkan suatu masalah dan lain-lain.

Setiap metode yang digunakan memiliki kelebihan dan kekurangan, begitu juga dengan metode problem solving. Metode ini memiliki kelebihan sesuai dengan Alifandie (1984 : 93) menyatakan bahwa kelebihan Problem Solving adalah sebagai berikut :

a. Masing-masing peserta didik diberi kesempatan yang sama dalam mengeluarkan pendapatnya, sehingga para peserta didik merasa lebih dihargai dan nantinya akan menumbuhkan rasa percaya diri

b. Para peserta didik diajak untuk lebih menghargai pendapat orang lain

c. Untuk membantu peserta didik dalam mengembangkan lisannya.

d. Anak-anak menjadi terbiasa mengisi waktu senggangnya dengan hal-hal konstruktif.

e. Memupuk rasa tanggung jawab dan harga diri atas segala tugas yang dikerjakan, sebab metode ini sekaligus juga mengharuskan murid untuk bertanggungjawabkan hasil pekerjaannya kepada guru.

f. Melatih anak berfikir kritis, tekun, giat dan rajin belajar.

g. Pengetahuan yang diperoleh anak dari hasil belajar akan lebih mendalam dan lama tersimpan dalam ingatan.

Di samping beberapa keunggulan dan kelebihan yang diperoleh dengan penggunaan metode problem solving dalam proses belajar mengajar, terdapat juga beberapa kelemahan-kelemahan metode ini. Menurut Sriyono (1989: 112) kelemahan tersebut adalah :

a. Karena tidak melihat kualitas pendapat yang di sampaikan terkadang penguasaan materi sering terabaikan

b. Metode ini seringkali menyulitkan mereka yang sungkan mengutarakan pendapat secara lisan

c. Sulit memberikan tugas yang sesuai dengan masing-masing individu.

Problem Solving dapat merangsang peserta didik agar dapat berbuat aktif dalam belajar baik secara individu maupun secara kelompok. Problem solving dapat diberikan kepada peserta didik secara individu maupun secara kelompok. 


\section{METODE PENELITIAN}

Penelitian ini dilaksanakan di SDN 12 Nan Sabaris pada siswa kelas IV. Penelitian ini menggunakan metode penelitian tindakan kelas. Langkah-langkah penelitian tindakan kelas dapat dijelaskan berikut ini.

\section{Rencana Kegiatan Siklus I}

Dalam penelitian tindakan kelas, prosedur dan langkah-langkah penelitian yang dilakukan adalah perencanaan tindakan, pelaksanaan tindakan, observasi dan evaluasi dan refleksi, langkah-langkah tersebut dilaksanakan secara bersiklus.

\section{1) Perencanaan}

Sebelum dilakukan kegiatan dalam kelas guru (peneliti) menyiapkan dan menyusun rencana pelajaran yang memuat tujuan yang akan dicapai, materi, metode dan lainnya, menyiapkan latihan yang akan diberikan kepada peserta didik. Di samping itu juga mempersiapkan instrumen berupa pedoman observasi yang akan digunakan.

2) Pelaksanaan Tindakan

Tindakan dimulai dengan guru menjelaskan materi pelajaran sesuai dengan pokok bahasan serta dengan memberikan contoh-contoh soal, peserta didik diberi kesempatan untuk mencatat contoh-contoh soal dalam buku catatan peserta didik, beberapa orang peserta didik disuruh menyelesaikan soal beberapa buah ke depan kelas.

\section{3) Observasi dan Evaluasi}

Selama kegiatan pembelajaran berlangsung, teman sejawat membantu mengamati pelaksanaan perbaikan, baik terhadap guru yang mengajar maupun kegiatan peserta didiknya.

\section{4) Refleksi}

Pada akhir silkus diadakan refleksi terhadap kegiatan dan hasil-hasil yang diperoleh berdasarkan hasil observasi kolaborator, catatan yang dibuat guru dan hasil tugas yang dikerjakan oleh peserta didik. Hasil refleksi ini akan dijadikan dasar untuk menyusun rencana tindakan pada siklus berikutnya.

\section{Rencana Kegiatan Siklus II}

Langkah-langkah yang dilakukan dalam siklus II ini sama dengan tidakan yang dilakukan pada siklus I.

Pada siklus II ini dilakukan perbaikan yang belum terlaksana atau belum tercapai pada siklus I.

Instrumen yang digunakan dalam Penelitian Tindakan Kelas ini adalah:

a. Pedoman observasi untuk mengecek kegiatan yang dilakukan berdasarkan indikator yang ditentukan sebelumnya.

b. Catatan tentang kejadian yang terjadi selama tindakan diberikan, baik yang positif maupun yang negatif.

c. Di samping itu juga digunakan lembar tugas dan nilai yang diperoleh peserta didik selama proses belajar berlangsung.

Setelah data tentang kemampuan peserta didik kelas IV Sekolah Dasar Negeri 12 Nan Sabaris dan minat peserta didik dalam belajar bidang studi Matematika serta data tentang kemampuan peserta didik dalam prestasi belajar peserta didik telah terkumpul, maka akan diadakan analisis data. menemukan apa yang penting dan apa yang akan peneliti laporkan (Bogdan dan Biklen, 1982 : 23)

\section{HASIL DAN PEMBAHASAN PENELITIAN}

\section{Kegiatan Perbaikan pada Siklus I}

\section{Pelaksanaan Tindakan}

Sesuai dengan perencanaan, maka peneliti melaksanakan kegiatan belajar mengajar di kelas IV yang peneliti jadikan sebagai objek penelitian. Adapun langkah-langkahnya sebagai berikut :

1) Melaksanakan tes awal

2) Menjelaskan materi tentang hitungan bilangan campuran.

3) Memberi kesempatan kepada peserta didik untuk bertanya.

4) Menjelaskan kembali 
5) Memberikan kesempatan kepada peserta didik untuk mencatat materi dalam catatan

6) Memberikan latihan

7) Menanya peserta didik tentang materi yang belum diketahui.

8) Memberikan latihan lanjutan

9) Mengawasi dan mengontrol peserta didik dalam mengerjakan latihan.

10) Mengumpulkan latihan

11) Beberapa peserta didik menuliskan jawaban ke papan tulis

12)Akhir pelajaran; Peneliti menyimpulkan materi dan memberikan peserta didik tugas untuk dikerjakan di rumah.

\section{Pengamatan}

Untuk mengetahui hal-hal yang mempengaruhi pencapaian hasil belajar matematika peserta didik, maka perlu diamati tingkah laku dan kegiatan peserta didik selama proses belajar mengajar berlangsung. Dari hasil pengamatan yang dilakukan, kegiatan positif dan negatif peserta didik dapat dilihat dari tabel di bawah ini.

Tabel 1

Kegiatan positif peserta didik selama proses belajar mengajar pada siklus I

\begin{tabular}{|l|l|l|l|l|}
\hline \multirow{2}{*}{ No } & Kegiatan Positif Peserta didik & \multicolumn{2}{|l|}{ Frekuensi } & \multirow{2}{*}{ Ket. } \\
\cline { 3 - 5 } & & $\begin{array}{l}\text { Peserta } \\
\text { didik }\end{array}$ & \% & \\
\hline 1. & Memperhatikan guru menjelaskan & 9 & 60 & \\
2. & Terlibat aktif dalam PBM & 8 & 53 & \\
3. & Mengajukan pertanyaan tentang materi yang belum & 4 & 27 & \\
& dipahami. & & 67 & \\
4. & Mengerjakan latihan sendiri & 10 & 67 & \\
5. & Menuliskan hasil kerja didepan kelas & 6 & 40 & \\
6. & Berani menyelesaikan soal kedepan kelas. & 5 & 33 & \\
7. & Mengerjakan pekerjaan rumah & 13 & 87 & \\
\hline Jumlah & & 367 & $52,42 \%$ & \\
\hline Rata-rata & & & \\
\hline
\end{tabular}

Dari tabel 1 di atas dapat dikemukakan bahwa kegiatan positif peserta didik di antaranya adalah :

1) Peserta didik yang memperhatikan guru menjelaskan materi sebanyak 9 orang dari 15 orang peserta didik yang hadir,

2) Peserta didik yang terlibat aktif dalam proses belajar mengajar sebanyak 8 orang (sebesar $53 \%$ )

3) Persentase peserta didik yang mau mengajukan pertanyaan tentang materi yang belum dipahami sangat kurang sekali hanya sebesar 4 orang

4) Peserta didik yang mengerjakan latihan sendiri sebanyak 10 orang, jika dipersentasekan hanya sebesar $67 \%$, ini berarti masih ada di antara peserta didik yang belum dapat mengerjakan latihan sendiri

5) Persentase menuliskan hasil kerja ke depan kelas sebesar $60 \%$

6) Dalam proses belajar mengajar berlangsung peserta didik yang berani menyelesaikan soal kedepan kelas hanya sekitar $33 \%$.

7) Peserta didik yang mengerjakan pekerjaan rumah, sebanyak 13 orang (sebesar 87\%) 
Kegiatan positif yang dilakukan peserta didik dalam proses belajar mengajar hanya mencapai persentase $52,43 \%$, jika dilihat persentase seperti yang terdapat pada tabel di bawah ini.

Tabel 2

Kegiatan negatif peserta didik dalam proses belajar mengajar pada siklus I

\begin{tabular}{|l|l|l|l|l|}
\hline \multirow{2}{*}{ No. } & \multirow{2}{*}{ Kegiatan Negatif Peserta didik } & \multicolumn{2}{|l|}{ Frekuensi } & \multirow{2}{*}{ Ket. } \\
\cline { 3 - 4 } & & Peserta didik & $\%$ & \\
\hline 1. & Tidak mengerjakan latihan & 3 & 20 & \\
2. & Bermain sendiri & 4 & 27 & \\
3. & Minta izin keluar & 1 & 7 & \\
4. & Menganggu teman & 3 & 20 & \\
5. & Tidak membawa peralatan & 3 & 20 & \\
6. & Peserta didik yang suka menyontek & 6 & 40 & \\
7. & Peserta didik yang suka berbicara dalam belajar & 5 & 33 & \\
\hline Jumlah & & & 167 & \\
\hline Rata-rata & & $23,86 \%$ & \\
\hline
\end{tabular}

Dari tabel 2 di atas kegiatan negatif yang dilakukan peserta didik yang dapat dicermati bah Masih ditemukan bahwa peserta didik yang tidak mengerjakan latihan yaitu sebanyak 3 orang. Peserta didik sebanyak 4 orang (sebesar 27\%) asyik bermain-main sendiri, walau peneliti sudah memberi teguran kepada peserta didik tersebut. Hanya 1 atau 7\% peserta didik yang keluar kelas minta izin. Persentase peserta didik yang mengganggu teman dalam belajar sebesar $20 \%$ atau sebanyak 3 orang. Persentase peserta didik yang tidak membawa perlengkapan menulis sebesar $20 \%$ atau 3 orang. Peserta didik yang suka menyontek ada 6 orang. Peserta didik yang suka berbicara saat guru/peneliti menjelaskan dan saat mengerjakan tugas ada sebanyak 5 orang atau sebesar $30 \%$.

Hasil pengamatan terhadap kegiatan positif dan kegiatan negatif peserta didik dalam proses belajar mengajar dapat kita lihat hasil belajar matematika yang diperoleh peserta didik dengan penggunaan metode problem solving dengan pemberian latihan beberapa buah soal sekaligus pada siklus I ini, seperti tabel di bawah ini :

Tabel 3

Hasil belajar Matematika Peserta didik Kelas IV dengan Metode problem solving pada siklus I

\begin{tabular}{|l|l|l|l|l|}
\hline \multirow{2}{*}{ No } & \multirow{2}{*}{ Nama Siswa } & \multirow{2}{*}{ Nilai } & \multicolumn{2}{|l|}{ Ketuntasan } \\
\cline { 4 - 5 } & & & Tuntas & Tidak Tuntas \\
\hline 1 & Muhammad Hidayat & 60 & - & $\sqrt{ }$ \\
\hline 2 & M. Fadil Rivaldi & 65 & - & $\sqrt{ }$ \\
\hline 3 & Marniwati & 60 & - & $\sqrt{ }$ \\
\hline 4 & Permata Audia & 70 & - & $\sqrt{ }$ \\
\hline 5 & Riandika Saputra & 85 & $\sqrt{ }$ & - \\
\hline 6 & Rian Herman Purta & 80 & $\sqrt{ }$ & - \\
\hline 7 & Rasmita Selvi & 75 & $\sqrt{ }$ & - \\
\hline 8 & Sultan Rizki fajar & 90 & $\sqrt{ }$ & - \\
\hline
\end{tabular}




\begin{tabular}{|l|l|l|l|l|}
\hline 9 & Syeverlika Fardila & 85 & $\sqrt{ }$ & - \\
\hline 10 & Yola Karmila & 70 & - & $\sqrt{ }$ \\
\hline 11 & Yeni Oktavia & 60 & - & $\sqrt{ }$ \\
\hline 12 & Zindi Yunita Sari & 80 & $\sqrt{ }$ & - \\
\hline 13 & Nofri Alfarezi & 60 & - & $\sqrt{ }$ \\
\hline 14 & Rahmat Hidayat & 90 & $\sqrt{ }$ & - \\
\hline 15 & Febi Nirwana & 80 & $\sqrt{ }$ & - \\
\hline Jumlah & 1110 & & \\
\hline Rata-rata & 74,00 & & \\
\hline Nilai Tertinggi & 90 & & \\
\hline Nilai Terendah & 60 & & \\
\hline
\end{tabular}

Dari hasil belajar 15 peserta didik tersebut, terlihat bahwa nilai tertinggi yang berhasil dicapai dengan nilai 90 hanya 1 orang, sedangkan nilai terendah adalah 60 sebanyak 4 orang. Berdasarkan sebaran nilai tersebut dapat digambarkan bahwa peserta didik yang memperoleh nilai 75 ke atas sebanyak 8 orang (53\%), peserta didik yang memperoleh nilai 70 ke bawah sebanyak 7 orang $(47 \%)$.

\section{Refleksi}

Secara umum belum ada terjadinya peningkatan hasil belajar matematika peserta didik dengan menggunakan metode problem solving dengan pemberian tugas secara keseluruhan di mana masih rendahnya nilai peserta didik.

\section{Kegiatan Perbaikan Pada Siklus II Pelaksanaan Tindakan}

Berdasarkan hasil belajar Matematika yang diperoleh peserta didik pada siklus I dan refleksi yang dilakukan di mana hasil belajar Matematika yang diperoleh peserta didik belum mencapai indikator yang telah ditetapkan. Masih diperlukan tindakan yang dapat meningkatkan hasil belajar peserta didik. Pada siklus II ini tindakan yang dilakukan sama dengan tindakan yang dilakukan pada siklus I, yang berbeda hanya cara bertahap.

\section{Pengamatan}

Kegiatan peserta didik selama belajar dalam siklus ke dua ini dapat dilihat pada tabel berikut :

Tabel 4

Kegiatan positif peserta didik pada KBM siklus II

\begin{tabular}{|l|l|l|l|l|}
\hline \multirow{2}{*}{ No. } & \multirow{2}{*}{ Kegiatan Positif Peserta didik } & \multicolumn{2}{|l|}{ Frekwensi } & \multirow{2}{*}{ Ket. } \\
\cline { 3 - 5 } & & Peserta didik & \% & \\
\hline 1. & Memperhatikan guru menjelaskan & 13 & 87 & \\
2. & Terlibat aktif dalam PBM & 12 & 80 & \\
3. & Mengajukan pertanyaan tentang materi. & 8 & 53 & \\
4. & Mengerjakan latihan sendiri & 15 & 100 & \\
5. & Menuliskan hasil kerja didepan kelas & 10 & 67 & \\
6. & Berani menyelesaikan soal kedepan kelas. & 7 & 47 & \\
\hline
\end{tabular}




\begin{tabular}{|l|l|l|l|l|}
\hline 7. & Mengerjakan pekerjaan rumah & 15 & 100 & \\
\hline Jumlah & & 534 & \\
\hline Rata-rata & & 76,29 & \\
\hline
\end{tabular}

Berdasarkan hasil dari pengamatan positif peserta didik selama proses belajar berlangsung, maka terlihat :

1) Peserta didik yang memperhatikan guru menjelaskan materi sebanyak 13 orang dengan persentase $87 \%$.

2) Keaktifan peserta didik dalam proses belajar mengajar sudah mencapai 12 orang dengan presentase $80 \%$.

3) Persentase materi yang belum dipahami masih 8 orang, selebihnya peserta didik tersebut tetap diam.

4) Persentase peserta didik sudah mau mengerjakan sendiri latihannya sebesar $100 \%$ atau sebanyak 15 orang

5) Aktivitas peserta didik untuk mengerjakan latihan ke depan kelas sebanyak 10 orang peserta didik.

6) Peserta didik yang berani mengerjakan soal ke depan kelas sudah mengalami perubahan.

7) Peserta didik yang mengerjakan PR sebesar $100 \%$ (sebanyak 12 orang)

Berdasarkan uraian di atas, pada siklus II ini hasil pembelajaran dapat kita lihat pada tabel di bawah ini :

Tabel 5

Hasil belajar Matematika Peserta didik Kelas IV dengan Metode problem solving pada siklus II

\begin{tabular}{|l|l|l|l|l|}
\hline \multirow{2}{*}{ No } & \multirow{2}{*}{ Nama Siswa } & \multirow{2}{*}{ Nilai } & \multicolumn{3}{|l|}{ Ketuntasan } \\
\cline { 4 - 5 } & & & Tuntas & Tidak Tuntas \\
\hline 1 & Muhammad Hidayat & 75 & $\sqrt{ }$ & - \\
\hline 2 & M. Fadil Rivaldi & 80 & $\sqrt{ }$ & - \\
\hline 3 & Marniwati & 75 & $\sqrt{ }$ & - \\
\hline 4 & Permata Audia & 80 & $\sqrt{ }$ & - \\
\hline 5 & Riandika Saputra & 95 & $\sqrt{ }$ & - \\
\hline 6 & Rian Herman Purta & 90 & $\sqrt{ }$ & - \\
\hline 7 & Rasmita Selvi & 90 & $\sqrt{ }$ & - \\
\hline 8 & Sultan Rizki fajar & 100 & $\sqrt{ }$ & - \\
\hline 9 & Syeverlika Fardila & 95 & $\sqrt{ }$ & - \\
\hline 10 & Yola Karmila & 80 & $\sqrt{ }$ & - \\
\hline 11 & Yeni Oktavia & 75 & $\sqrt{ }$ & - \\
\hline 12 & Zindi Yunita Sari & 90 & $\sqrt{ }$ & - \\
\hline 13 & Nofri Alfarezi & 75 & $\sqrt{ }$ & - \\
\hline 14 & Rahmat Hidayat & 100 & $\sqrt{ }$ & - \\
\hline 15 & Febi Nirwana & 100 & $\sqrt{ }$ & - \\
\hline Jumlah & 1300 & & \\
\hline Rata-rata & 86,67 & & \\
\hline Nilai Tertinggi & 100 & & \\
\hline Nilai Terendah & 75 & & \\
\hline
\end{tabular}


Untuk lebih jelasnya skor perolehan dan nilai rata-rata dari kedua siklus kedua siklus dengan menggunakan metode problem solving ini dapat dilihat pada tabel berikut :

Tabel 6

Rata-Rata Hasil Belajar Siklus I Dan II

\begin{tabular}{|l|l|l|l|}
\hline \multirow{2}{*}{ No } & \multirow{2}{*}{ Variabel } & Metode Problem Solving \\
\cline { 3 - 4 } & & Siklus I & Siklus II \\
\hline 1 & Jumlah Peserta didik & 15 & 15 \\
\hline 2 & Skor Tertinggi & 90 & 100 \\
\hline 3 & Skor Trendah & 60 & 75 \\
\hline 4 & Jumlah Nilai & 1110 & 1300 \\
\hline 5 & Nilai rata-rata & 74,00 & 86,67 \\
\hline
\end{tabular}

Melihat perbandingan hasil belajar siklus I dengan siklus II di atas, maka dapat kita ambil kesimpulan bahwa dengan metode problem solving yang digunakan pada kedua siklus ini dapat diukur berdasarkan angka rata-rata diperoleh peserta didik pada akhir pembelajaran.

\section{Refleksi}

Secara umum dapat dikatakan tindakan yang dilakukan pada siklus ke dua telah dapat meningkatkan kegiatan pada partisipasi peserta didik-peserta didik serta dapat meningkatkan hasil belajar matematika peserta didik. Kesimpulan ini diperoleh dari : pertama dapat meningkatkan perhatian peserta didik saat meneliti menjelaskan materi yaitu dari 9 orang menjadi 13 orang, peserta didik yang aktif dari 8 orang menjadi 12 orang, peserta didik yang mengerjakan latihan sendiri dari 6 orang menjadi 11 orang, menuliskan hasil kerja ke depan kelas dari 6 orang meningkat menjadi 10 orang. Berani menyelesaikan soal kedepan kelas dari 6 orang menjadi 9 orang dan mengerjakan pekerjaan rumah dari 11 orang menjadi 15 orang. Hanya saja yang belum mengalami peningkatan adalah belum adanya perubahan peserta didik yang mampu mengajukan pertanyaan tentang materi yang belum dipahami walaupun peneliti sudah memancing peserta didik untuk bertanya.

\section{PEMBAHASAN}

Penggunaan metode problem solving dengan cara bertahap oleh guru sekolah dasar pada mata pelajaran matematika sangat berpengaruh terhadap hasil belajar peserta didik. Hal ini dapat dibuktikan berdasarkan data hasil belajar pada siklus II lebih tinggi nilainya dibanding nilai pada siklus

Berdasarkan temuan-temuan di lapangan dan analisa data yang telah dikemukakan pada bab terdahulu, muka bab-bab ini akan dikemukakan kesimpulan dari hasil penelitian serta acuan yang dirasa perlu untuk dikemukakan.

\section{KESIMPULAN}

Dari hasil penelitian dan tindakan dikemukakan pada bab terdahulu dapat ditarik kesimpulan sebagai berikut :

a. Hasil belajar peserta didik pada siklus II sebesar 86,67 dan hasil belajar pada siklus I dengan pemberian latihan secara keseluruhan sebesar 74,00.

b. Pemberian latihan secara kontiniu dapat meningkatkan kemandirian peserta didik dalam mengerjakan latihan.

c. Dapat meningkatkan rasa percaya diri dan adanya kemauan peserta didik untuk mengerjakan soal

d. Pemberian latihan secara kontiniu dapat meningkatkan pemahaman peserta didik terhadap materi yang diajarkan. 


\section{SARAN} berikut :

Berdasarkan hasil penelitian tindakan kelas yang telah dikemukakan di atas diajukan saran-saran sebagai

1. Dalam setiap pembelajaran Matematika guru sebaiknya menggunakan metode problem solving di samping metoda-metoda mengajar yang lain yang sesuai.

2. Sebaiknya guru mengawasi dan mengontrol peserta didik dalam mengerjakan latihan dalam rangka meningkatkan hasil belajar Matematika peserta didik.

3. Diharapkan kepada kepala sekolah dan instansi terkait agar mengajarkan para guru untuk menggunakan metode problem solving secara bertahap untuk meningkatkan hasil belajar Matematika peserta didik.

4. Diharapkan kepada para guru agar melakukan penelitian lanjutan dalam penggunaan metode problem solving sehingga nantinya dapat meningkatkan hasil belajar Matematika peserta didik ke arah yang lebih sempurna.

\section{DAFTAR PUSTAKA}

Muhammad Ali, 1983. Guru dalam Proses Belajar Mengajar, Bandung. PT. Sinar Baru Algensindo.

Imansjah Alipandie, 1984. Didaktik Metodik. Surabaya. Usaha Nasional.

Tengku Zakaria Djaafar, 2001. Kontribusi Strategi Pembelajaran Terhadap Hasil Belajar. Jakarta. Universitas Negeri Padang.

Mudjiono, 1991/1992. Strategi Belajar Mengajar. Jakarta. Depdikbud Direktorat Jenderal Pendidikan Tinggi Proyek Pembinaan Tenaga Kependidikan.

Nana Sudjana, 1989. Dasar-dasar Proses Belajar Mengajar. Bandung. Sinar Baru Algensindo.

Sriyono, 1989. Teknik Belajar Mengajar Dalam CBSA, Jakarta. Dineka Cipta.

Tarsis Tarmudji, 1983. Metoda dan Media. Yokyakarta. Liberty.

I.G.A.K Wardani, 2012. Penelitian Tindakan Kelas. Jakarta. Pusat Penerbitan Universitas Terbuka.

Udin S. Winataputra, 1997. Strategi Belajar Mengajar. Jakarta. Depdikbud Proyek Mutu Guru Kelas SD Setara D II. 